\title{
FOREST FRAGMENTATION IN AN AFRICAN BIODIVERSITY HOTSPOT IMPACTS MIXED-SPECIES BIRD FLOCKS
}

Norbert J. Cordeiro ${ }^{1,2, *}$, Luca Borghesio ${ }^{3}$, Martin P. Joho ${ }^{4}$, Teodora J. Monoski ${ }^{1}$, Victor J.

Mkongewa ${ }^{4}$ and Corinna J. Dampf ${ }^{1}$

${ }^{1}$ Department of Biological, Chemical, and Physical Sciences, Roosevelt University, $430 \mathrm{~S}$.

Michigan Avenue, Chicago, IL 60605, USA

${ }^{2}$ Departments of Botany and Zoology, Field Museum of Natural History, 1400 S. Lake Shore Drive, Chicago, IL 60605, USA

${ }^{3}$ Corso Re Umberto 42, 10128, Torino, Italy

${ }^{4}$ BirdLife International-Tanzania Office, c/o PO Box 29, Amani, Muheza District, Tanzania

Luca Borghesio: borghesio@gmail.com

Martin P. Joho: martinjoho2008@yahoo.com

Teodora J. Monoski: tjm66680@ gmail.com

Victor J. Mkongewa: victormkongewa@yahoo.com

Corinna J. Dampf: cdampf37@gmail.com

*corresponding author (N.J. Cordeiro: ncordeiro@ fieldmuseum.org; ncordeiro@ roosevelt.edu) 


\begin{abstract}
The effect of forest fragmentation on mixed-species foraging bird flocks has been poorly evaluated, particularly in African forests. We examined the consequences of forest fragmentation on such flocks in the East Usambara Mountains, Tanzania, by addressing ecological as well as behavioural components. We counted these flocks in five small $(<31 \mathrm{ha})$, isolated fragments and six widely spaced continuous forest sites. Given that flock cohesion and stability might be facilitated via positive interactions of leader or nuclear species, we focused on one putative nuclear species, the square-tailed drongo (Dicrurus ludwigii), and using playback of its vocalisations, we evaluated (i) if its vocalisations attracted flocking birds as expected by a nuclear species, and (ii) if loss of this species in fragments contributed to flock declines. We found that flocks in forest fragments had smaller sizes, reduced species richness, a reduced proportion of understorey specialists, a higher proportion of forest generalists and non-forest species, and were more variable in size and composition compared to flocks observed in continuous forest. Furthermore, flocks in fragments were composed of a higher proportion of omnivores than insectivores. Despite lower absolute abundance in fragments, $D$. ludwigii was observed in $86 \%$ of natural occurring flocks in both fragments and continuous forest, and flocks with $D$. ludwigii were significantly larger than those without it - especially in the continuous forest. Playback vocalisations of $D$. ludwigii attracted flocks of similar abundance and species richness in fragments and continuous forest, but a vastly different composition, confirming (i) its nuclear role and (ii) that, in fragments, flock assemblages had a distinct composition, with a high proportion of forest generalists and non-forest species. Loss or diminished abundance of nuclear species due to fragmentation may be an important factor that affects the presence and composition of mixed-species flocks. Given that $67 \%$ of flocking species forage in the understorey, and that insectivores were more negatively affected in fragments than omnivores, the implications of our findings are relevant for conservation in tropical forests.
\end{abstract}

Keywords: avian flocks; Eastern Arc; experimental playback; forest fragmentation; nuclear species; mutualism

\title{
1. Introduction
}

Mixed-species foraging flocks (hereafter mixed-species flocks) are common in avian communities globally (Moynihan, 1962; Hutto, 1994), but are especially important components of tropical forests (Munn and Terborgh, 1979; Powell, 1985; Thiollay, 1999; Sridhar et al., 2009). These groups of different bird species move and forage together (Swynnerton, 1915; McClure, 1967), and are considered important in structuring avian communities (Vernon, 1980; Terborgh, 1990). A number of ecological, fitness and social advantages have been attributed to mixed-species flock formation (Greenberg, 2000), including increased foraging efficiency (Clark and Mangel, 1984; Hino 1998, Satischandra et al., 2007), and protection from potential predators while in the flock (Terborgh, 1990; Thiollay, 1999; Sridhar et al., 2009). Ultimately, regularity of participation in such flocks increases survival odds (Jullien and Clobert, 2000; Cruz-Angón et al., 2008), and can thus be a measure of fitness, likely explaining why such flocking behaviour is commonly encountered in various ecosystems.

Flock development, cohesion and stability are likely facilitated by the presence of one or more leader or nuclear species (Winterbottom, 1943; Hutto, 1994; Goodale and Beauchamp, 2010). Nuclear species are defined as those species that lead flocks, behave conspicuously, occur in a high proportion of flocks and are rarely found outside of such flocks (Hutto, 1994). These characteristics may make a nuclear species easy to identify and follow through dense foliage, conferring a variety of advantages to other flock participants, as well as on the nuclear species itself (Goodale and Beauchamp, 2010). Two types of nuclear species have been identified: those that 
function as 'sentinels' (Greig-Smith, 1981) versus those that are 'intraspecifically gregarious' (see Goodale and Kotagama, 2005). Using playback experiments, either or both of these types of isolated forest patches, is one of the leading agents of species extinctions at local and global scales (Newmark, 1991; Şekercioğlu et al., 2002; Bregman et al., 2014). Fragmentation might affect flock formation via the loss of nuclear species (see Stouffer and Bierregaard, 1995; Maldonado-Coehlo and Marini, 2000; Lee et al., 2005). Moreover, the structure and cohesion of foraging flocks might be affected by reduced representation of specific foraging guilds. For instance, understorey insectivores are among the guilds most vulnerable to fragmentation (Newmark, 1991; Stouffer and Bierregaard, 1995; Şekercioğlu et al., 2002; Arcilla et al., 2015; Buechley et al., 2015), and many species in this guild frequently participate in mixed-species flocks (Stouffer and Bierregaard, 1995; van Houtan et al., 2006; Goodale et al., 2013). Until recently, few studies have examined the effects of forest fragmentation and other human-aided disturbances on such flocks, and these have been limited largely to the Neotropics and Australasia (Stouffer and Bierregaard, 1995; MaldonadoCoehlo and Marini, 2000; Maldonado-Coehlo and Marini, 2004; Lee et al., 2005; van Houtan et al., 2006; Sridhar and Sankar, 2008; Mokross et al., 2014; Goodale et al., 2014). In Afrotropical forests, many of which continue to be fragmented or degraded at alarmingly high rates (Rudel, 2013), the stability and diversity of mixed-species flocks remain practically unstudied.

The Eastern Arc Mountains of Tanzania and south-eastern Kenya (Brooks et al., 2002) is one of the most globally-threatened biodiversity hotspots. Long-term research from the East Usambara Mountains (Newmark, 1991; henceforth EUM), which are one of the northern blocks that comprise the Eastern Arc, has demonstrated that understorey insectivores are locally extinct or in very reduced abundances from fragments as small as 31 ha and isolated by extensive tea plantations. Many of these understorey species are regular components of flocks in continuous forest (NJC pers.obs.), and yet little is known about why they fail to persist in small fragments. We therefore sought to test the primary hypothesis that forest fragmentation in the EUM negatively impacted mixed-species flocks, and as a corollary, that loss of a putative nuclear species potentially contributes to declines in species that join such flocks.

Forest fragmentation reduces species richness, stability and composition of mixed-species flocks in Neotropical forests, and we expected the same to be true for the EUM. For example, working in the Atlantic forests of south-eastern Brazil, Maldonado-Coelho and Marini (2004) observed 356 flocks in nine forest fragments, and found that species richness and flock size were positively related to fragment area. They also found that flock stability increased with fragment area; results were generally comparable to an earlier study in fewer Atlantic forest fragments (Maldonado-Coelho and Marini, 2000). Based on the capture rates of species pre- and post-fragmentation, van Houtan et al. (2006) showed that species with a higher tendency for flocking behaviour were less likely to persist in small, isolated Amazonian fragments. Given high levels of fragmentation due to tea cultivation in the plateau region of the EUM, we first evaluated if species richness and individual abundance in mixed-species flocks was different in continuous forest versus small, isolated fragments. Furthermore, because insectivores are negatively affected by fragmentation in the EUM (Newmark, 1991), we divided the species that constituted mixed-species flocks into insectivores and omnivores in an effort to determine if guilds were heterogeneously affected by fragmentation. As the fragments chosen were isolated by tea plantations and not connected by secondary growth, we predicted that species richness, composition and abundance would be lower in isolated, small fragments as compared to continuous forest. We also predicted that omnivores would be less 
affected by fragmentation than insectivores due to their broader dietary needs (Şekercioğlu et al., 2002), and that in these two guilds, understorey species with more specialised niche requirements would experience the greatest reduction through fragmentation.

During our observational study on mixed-species flocks, and an earlier community level study from 2000-2001, we found that one putative sentinel species, the square-tailed drongo (D. ludwigii), was rare or absent from some small fragments in the EUM. We therefore used this to our advantage as a natural manipulation and performed playback experiments to test if (i) this was indeed a nuclear species, and (ii) if playback of its vocalisations induced species flocks in fragments as compared to the continuous forest. We selected this drongo species due to previous observations on its behaviour (NJC, pers. obs.), which suggested it was a "sentinel" nuclear species not unlike the greater racket-tailed drongo (Dicrurus paradiseus) of South Asian forests (Goodale and Kotagama, 2005; Satischandra et al., 2010). We reasoned that insectivores and other guilds use the vocalisations of nuclear species to locate flocks (Goodale and Kotagama, 2005), and that sentinels like the drongo provide a number of positive interactions for flock participants. Using observational data on mixed-species flocks and an experimental playback manipulation of an apparent nuclear species on mixed-species flocks, we provide important evidence on the role of nuclear species in this fragmented biodiversity hotspot. Moreover, our evidence suggests that sentinel nuclear species might be vital toward flock stability and cohesion, including facultative participants. Loss of nuclear species might therefore have important conservation implications, especially in tropical forests, which are rapidly being lost to deforestation worldwide.

\section{Methods}

\subsection{Study Area}

The study was conducted in Amani Nature Reserve and adjacent forest fragments (Fig. S1). Amani Nature Reserve is 8380 ha in size and includes lowland and submontane forest $\left(4^{\circ} 48^{\prime}-5^{\circ} 13^{\prime} \mathrm{S}\right.$, $38^{\circ} 32-48^{\prime} \mathrm{E}$ ), protecting one of the extensive wet forests of the EUM in northeastern Tanzania, which is part of the Eastern Arc Mountain range. Rising from the coast to $1506 \mathrm{~m}$, the EUM are renowned for exceptionally high biodiversity, and considered a centre for speciation for various taxa (Iversen, 1991; Burgess et al, 2007).

Forest loss and fragmentation on this plateau has been severe over the last two centuries, through clearing for tea estates and, to some extent, intensive subsistence cultivation (e.g. Hamilton and Bensted-Smith, 1989; Newmark, 1991), leading to >50\% loss in original forest cover (Newmark, 1998). Six remnant forest fragments $(0.5,2,9,16,21$ and 31 ha), surrounded by a homogeneous matrix of tea plantation and occurring at $900-1000 \mathrm{~m}$ in elevation were used in this study. Tea plantations are monospecific and short, up to $1 \mathrm{~m}$ high, with intensive use of fertilisers, herbicides and pesticides: bird diversity is therefore impoverished in this habitat (NJC, pers. obs.). The continuous forest ( $\sim 3500 \mathrm{ha}$ ) is within the nature reserve in the submontane plateau, and six widely separated sites were selected for this study (Fig. S1).

The climate is consistently wet for much of the year. Rain is sustained by constant flow of moist currents from the nearby Indian Ocean, but peak rains occur between mid-March to May and October-November, with a dry period from January to early March. The mean annual rainfall is around $2000 \mathrm{~mm}$, humidity is high, and the mean annual temperature at Amani is $20.6{ }^{\circ} \mathrm{C}$ (Hamilton and Bensted-Smith, 1989). Rather constant moisture in the submontane zone has produced a vegetation community dominated by a suite of tree species typical of wet forest. Canopy species that predominate include Allanblackia stuhlmannii, Cephalosphaera usambarensis, Parinari 
excelsa, Isoberlinia schefflerii, Greenwayodendron suaveolens, Anisophyllea obtusifolia, Myrianthus holstii, Macaranga capensis, Trilepisium madagascariensis, Strombosia scheffleri and

\subsection{Observational sampling of flocks}

Mixed-species flocks can be recognized when two or more species associate and move together in the same direction for about five minutes (Stotz, 1993), and we therefore used this cue to detect such flocks in the study area. We sampled mixed-species foraging flocks in five isolated forest fragments $(2,9,16,21$ and $31 \mathrm{ha})$, and six continuous forest sites, each more than $1.5 \mathrm{~km}$ from the nearest other site. From May to September 2004, we randomly visited the 11 sites. This five-month period is at the tail end of the heavy rains (May), and the beginning of the cold season (JuneAugust), and transitional warm to short rainy season (September; Hamilton and Bensted-Smith, 1989). From late August into September is when the majority of the forest bird community begins breeding, and prior to that is the non-breeding season (Moreau, 1936; Mkongewa et al., 2013).

At each site, we walked into the forest until we located a flock. Upon encountering a flock, we walked in the anticipated direction that the flock was moving, then allowed 5 minutes of settling time. Using $8 \times 40 \mathrm{~mm}$ binoculars, we observed each flock and recorded the species and the number of individuals of each species for 10 minutes. All observations were conducted between 0630 and $1130 \mathrm{AM}$, and never under rainy or windy conditions. We only counted one flock at each site in a day to satisfy the assumption that flocks were independent from each other. In forest fragments sampled on the same day, we chose fragments in the opposite direction, and far from each other, to minimize double counting flocks as previous observations indicated that some flocking species can fly over the tea plantations between adjacent fragments.

\subsection{Playback experiment of nuclear species}

"Sentinel" nuclear species can provide a number of positive interactions to flock attendants (Goodale and Kotagama, 2005). Sentinel nuclear species have an anti-predator function, and differ from interspecifically gregarious nuclear species, which provide anti-predation and foraging benefits (Hino, 1998; Goodale and Kotagama, 2005). Sentinel nuclear species enable other species to move rapidly through the foliage as they follow it, using consistent and conspicuous calling and sallying to attract attention to its location, and similarly, due to their active behaviour and attentiveness, warning participants of impending danger (Goodale and Kotagama, 2005). The square-tailed drongo (D. ludwigii) of the EUM exhibits many of these qualities (NJC, pers. obs.), and thereby served as a model putative sentinel nuclear species.

In May 2013, we conducted the playback experiment in fragments and continuous forest to evaluate (1) the efficacy of the D. ludwigii as a putative nuclear species, and (2) the response of flocking species in fragments where the drongo is mostly absent, as compared to the continuous forest, where it is present. Three continuous sites in Amani Nature Reserve, each $>0.75 \mathrm{~km}$ apart, and three, isolated forest fragments $(0.5,2$ and $9 \mathrm{ha})$ surrounded by tea plantations were selected for this experiment (Fig. S1).

Playbacks consisted of pre-recorded tracks and were classified into three different treatments: (a) a white noise control; (b) a non-flocking species, tambourine dove (Turtur tympanistria), common throughout the area, including fragments (Newmark, 1991; Cordeiro et al., 2009), and (c) the putative nuclear species, square-tailed drongo $(D$. ludwigii). Multiple playback recordings of the dove and drongo were acquired from colleagues whose recordings were from eastern Tanzania and south-east Kenya, including the study area. For the drongo, we included the entire repertoire and 
did not exclude true or false alarm calls (see Satischandra et al., 2010), which are characteristics of this species.

At each location, the treatments were played using an iPad equipped with a portable speakeramplifier (RadioShack Mini Audio Amplifier). To simulate an actual flocking call, the recordings were consistently projected at a volume comparable to their natural amplitude as judged by ear. A series of experimental three trials was conducted at each forest location $(n=18)$. Each trial took place between the hours of 6:00 to $10 \mathrm{AM}$ and 3:30 to 5:00 PM and included the treatment playback: control (white noise), non-flocking species (tambourine dove), and nuclear species (square-tailed drongo). Playback trials were performed when we entered a site and ensured that no mixed species flocks were apparent in the vicinity since we were testing if the playback of a putative nuclear species attracted loosely foraging species and ultimately facilitated the formation of a mixed species flock. Each of the three treatment recordings was $45 \mathrm{~s}$ long from start to finish, and was played three times with a $5 \mathrm{~s}$ reprieve between each repetition. After a $30 \mathrm{~s}$ lull, the cycle of treatment recordings were repeated a second time, and together, comprised a single replicate. For each treatment, we recorded the following within a 5 min period following playback: the species and the number of individuals of each species responding, and the type of response (i.e. direct or vocal). We noted a direct response when a bird was observed moving toward the playback, whereas a vocal response was noted when a bird vocalized in response to the playback within $10 \mathrm{~s}$. Two observers equipped with binoculars collected experimental data. An additional observer acted as the data recorder and controlled the treatment playbacks.

\subsection{Statistical Analysis}

We ran Generalized Linear Mixed Models (GLMM) in with package lme4 (Bates et al., 2013) in the R 2.15.2 environment (R Core Team, 2012). GLMM fit was examined with plots of fitted data versus standardized model residuals, which in all cases showed a satisfactory fit.

In the results, in keeping with Moran (2003) and Perneger (1998), we present untransformed GLMM probabilities. That is, we do not apply alpha-level corrections (e.g., Bonferroni or False Discovery Rate control (Verhoeven et al., 2005)) because these generate conservative results and inflated rate of Type II (false negative) error. As our study focuses on the effects of forest fragmentation on mixed-species flocks in East Africa, and our results have high relevance to conservation, we suggest that false-negative error should be minimized (Roback and Askins, 2005), because it could lead to underestimation of conservation threats.

All multivariate analyses were done in the vegan $2.0 \mathrm{R}$ package (Oksanen et al., 2013), except for SIMPER, which was performed with PAST 2.17 (Hammer et al., 2001). In the results, data are presented as mean $\pm \mathrm{SE}$.

\subsubsection{Observational data of flocks}

We used Generalized Linear Mixed Models with Poisson distribution and log-link to test the hypothesis that forest fragmentation affects flock size and species richness. Due to the small numbers of sites in our study, we focused on forest size as the main fragmentation parameter, and did not consider other potentially relevant factors, such as isolation or perimeter/area ratio. In the models, species richness and flock size were the response variables, while log-transformed forest area was entered as fixed effect. Forest area was centred and standardized as advised by Schielzeth (2010) to improve interpretability and comparability of regression coefficients. Sites (six continuous and five fragments) were entered as a random factor. We ran this analysis on three datasets: all the species together, and separately for insectivores and omnivores; feeding guilds were categorised using Birds of Africa (1982-2004). 
We hypothesized that fragmentation might impact forest-dependent species and understorey forest fragments, the proportion of individuals and species with generalist habitat requirements is expected to increase. To test this hypothesis, we used GLMMs with Gaussian error structure and direct link, where forest area was the fixed factor and site was entered as a random factor. The response variables were (a) the proportion of non-forest species or individuals and (b) the proportion of understorey species or individuals in a flock. Proportions were arcsin-square root transformed to improve model fit. The categorisation of each species as forest versus non-forest dependent was taken from Bennun et al. (1996). Forest dependent species are forest-interior species that occur primarily in undisturbed forest tracts that they depend on for breeding, whereas nonforest dependent include (i) species that inhabit and breed in secondary forest and forest strips, and may occur in the forest interior but are less abundant there (termed forest generalists), and (ii) species from other habitat types abutting forest that may visit but are not dependent on forest for their survival (Bennun et al., 1996). To understand the strata in which flocking species primarily foraged, we used the independent classifications conducted by 21 amateur and professional ornithologists who work in the forest habitats of eastern Africa (unpublished data). Species were then categorised into any of the following strata based on $>50 \%$ of observer classification to a particular category: understorey, canopy or broad (forages relatively equally in both the understorey and canopy).

We further compared species richness in fragments and continuous forest by plotting sample-based rarefaction curves and their unconditional 95\% confidence limits with software EstimatesS 9.1.0 (Colwell, 2013). Curves were rescaled to individuals (Gotelli and Colwell, 2001), and compared by observing the overlap of their confidence limits.

In a second step, we performed a multivariate ordination with Detrended Correspondence Analysis (Legendre and Legendre, 1998) to determine whether flocks in continuous forest and fragments differed in terms of their species composition. DCA is an appropriate method to analyse count data, and it uses chi-square distances, which avoid the double-zero problem, i.e. two flocks with different species composition might appear similar due to species that are absent from both flocks. In DCA, units of Axis 1 can be interpreted as the average value of the standard deviation of species turnover, so that a complete species turnover occurs in approximately four units (Legendre and Legendre, 1998). We used the entire set of 66 flocks and 48 species, and untransformed count data to perform the DCA ordination, and tested its significance through 999 permutations (Oksanen et al., 2013).

We assessed whether flocks in fragments were more variable in size and composition than those in continuous forest calculating Multivariate Dispersion (MD), a multivariate analogue of Levene's test for homogeneity of variances (Anderson, 2006). Significance of multivariate dispersion was evaluated with 999 permutations. Finally, we calculated Similarity Percentage (SIMPER (Clarke, 1993)), which is a method for assessing which taxa are primarily responsible for an observed multivariate difference between groups. In SIMPER and MD, the input matrix contained untransformed counts of the 66 flocks (each flock was kept separate), and we calculated similarity values with Bray-Curtis index, which is not affected by the double-zero problem.

Finally, we assessed the potential nuclear role of the square-tailed drongo (D. ludwigii). We used GLMM with Poisson distribution and log-ling to compare size and species richness in flocks with and without drongo in both habitats. Factors in these models were drongo (present/absent) and habitat (fragment versus continuous) as well as their interaction, plus site as random factor. We did 
not consider more complex models including date and time, as the number of flocks without drongos was low ( 5 in continuous forest, 4 in fragments). We used data recorded in a point count

\subsubsection{Playback experiment}

Analyses of the experiment followed a similar flow as those of the observational study, however, since the nature of the response of $D$. ludwigii to the playback of its calls is expected to differ from that of heterospecifics, we excluded $D$. ludwigii from all calculations of species richness and abundance. First, we used GLMMs to test the effects of the three experimental treatments on the number and species richness of birds attracted to the playback. Then, we used GLMMs to compare abundance and species richness of bird assemblages attracted by the playback of square-tailed drongo in continuous forest and fragments. We used DCA, MD and SIMPER to compare the species composition of flocks attracted by playback in the two types of habitats.

\section{Results}

\subsection{Observational data on flocks}

The 66 flocks ( 36 in continuous and 30 in fragmented forest) altogether contained 4597 individuals of 49 species; that is 3361 individuals and 41 species in continuous forest, and 1236 individuals and 39 species in fragments. Average flock size was $93.4 \pm 4.3$ individuals in continuous forest, versus $41.2 \pm 2.5$ in forest fragments, whereas species richness was respectively $21.2 \pm 0.8$ and $13.6 \pm 0.6$. Of the 49 flocking species, $35 \%$ were primarily understorey dwellers, $32 \%$ foraged in the understorey and in higher-level strata, and the remaining 33\% were canopy dwellers (refer to Table 2). Forest area had a major effect on both total number of individuals and total species richness, which were consistently higher in continuous forest than in forest fragments (GLMM, $\mathrm{p}<0.001$; Table 1). Significantly higher abundance and species richness in continuous forest was also observed when birds were split into omnivores and insectivores (GLMM, all $p \leq 0.001$, Table 1 ). The loss of species richness and abundance was more marked in insectivores than in omnivores (Fig.1a-d; two-tailed ttest comparing slopes of regression lines of insectivores and omnivores: $\mathrm{df}=16$ and $\mathrm{p}=0.02$ for both abundance and species richness). Accordingly, insectivores represented $51.7 \pm 1.1 \%$ of the individuals and $55.8 \pm 1.0 \%$ of species of flocks in continuous forest, but only $39.6 \pm 1.8 \%$ and $42.9 \pm 1.4 \%$ respectively in forest fragments.

In forest fragments, flocks had an increased component of canopy and forest-generalist and nonforest species, while understorey specialists and forest dependent species were less represented (Fig. 1e-h, Table 1). Accordingly, understorey specialists made $12.9 \pm 0.7 \%$ of individuals and $19.9 \pm 1.0 \%$ of species in flocks observed in continuous forest, but only $8.8 \pm 1.0 \%$ of individuals and $10.7 \pm 1.2 \%$ of species in forest fragments. Forest generalists and non-forest species went from $26.6 \pm 1.0 \%$ of individuals and $32.2 \pm 1.3 \%$ of species in continuous forest, to $39.4 \pm 1.6 \%$ of individuals and $47.0 \pm 1.6 \%$ of species in fragments.

Confidence intervals of rarefaction curves overlapped broadly (Fig. 2a), suggesting that the lower species richness of flocks in forest fragments was due to the smaller number of individuals that compose these flocks, and not to a smaller pool of species from which the flocks were drawn. 
DCA ordination showed that convex hulls enclosing flocks observed in continuous forest and forest fragments overlapped in part (Fig. 3a), but nevertheless group centroids were significantly

SIMPER analysis showed that seven species (four omnivores and three insectivores; Table 2) contributed more than $50 \%$ of observed multivariate dissimilarity between flocks in forest fragments and continuous forest. In general, these species were observed only slightly less frequently in fragment flocks, but showed more substantial decrements in individual abundance (>40\%) in forest fragments. Among the 21 species with intermediate (1-4\%) contribution to multivariate dissimilarity, abundances and frequencies were generally lower in forest fragments, but seven species (Anthreptes pallidigaster, Pogoniulus leucomystax, D. ludwigii, Nectarinia olivacea, Stactolaema leucotis, Andropadus virens and Terpsiphone viridis) had rather similar abundance and frequency in the two habitats. Ten of 20 species with multivariate contribution equal or less than $1 \%$ were equally or more frequent in flocks observed in forest fragments. These results suggest that in forest fragments, mixed-species foraging flocks tend to lose individuals of regularly flocking (usually forest-dependent) species, but gain a number of irregularly flocking, mostly forest generalists and non-forest species.

The frequency at which $D$. ludwigii was observed in foraging flocks was very similar in continuous forest and in fragments (86.1\% versus $86.7 \%$ respectively; Table 2 ). However, in the point count study, relative density of $D$. ludwigii was three times as high in continuous forest than in the fragments $(2.2 \pm 0.3$ versus $0.7 \pm 0.3$ inds/point; GLMM, $\mathrm{p}<0.0001)$. Flocks with $D$. ludwigii were larger than those without this species (excluding $D$. ludwigii: Continuous forest: $72.6 \pm 12.5$ versus 94.0 \pm 9.2 individuals; Fragments $36.8 \pm 20.6$ versus $39.9 \pm 4.2$; GLMM: D. ludwigii presence $\mathrm{p}<$ 0.0001 , habitat $\mathrm{p}<0.0001, D$. ludwigii $\mathrm{X}$ habitat interaction $\mathrm{p}=0.43$ ). There was no difference in species richness in flocks with and without $D$. ludwigii (Continuous forest: $20.2 \pm 3.5$ versus $20.3 \pm 1.7$ species/flock; Fragments 12.0 \pm 5.1 versus 12.8 \pm 1.0 ; GLMM: D. ludwigii presence $\mathrm{p}=$ 0.80 , habitat $\mathrm{p}<0.01, D$. ludwigii $\mathrm{X}$ habitat interaction $\mathrm{p}=0.83$ ).

\subsection{Playback experiment}

Playback vocalisations of $D$. ludwigii attracted significantly more individuals (17.8 \pm 1.7$)$ and species (3.5 \pm 0.8 ) of birds per replicate than the two other playback treatments (GLMM, $\mathrm{p}<0.0001$ ). White noise and tambourine dove vocalisations did not differ between them (GLMM, $p=0.14$; average number of individuals and species attracted, white noise: $0.06 \pm 0.06$, tambourine dove: $0.39 \pm 0.18$ ). Assemblages of birds attracted by the drongo vocalisations did not differ between continuous forest and forest fragments in terms of number of individuals and species richness (GLMM, effect of habitat type on number of individuals, $\mathrm{p}=0.08$; on species richness, $\mathrm{p}=0.25$ ).

Confidence intervals of rarefaction curves of birds attracted by drongo vocalisation in continuous forest and forest fragments overlapped broadly (Fig. 2b), suggesting that the two species assemblages were drawn from similarly-sized species pools in the two habitats. Flocks attracted by D. ludwigii vocalisations in fragments were equally variable in terms of species composition as 
those attracted in continuous forest (MD analysis permutation test, $\mathrm{p}=0.88$ ).

Multivariate ordination with DCA showed that species composition of flocks attracted by playback was significantly different between continuous forest and forest fragments (Fig. 3b; permutation test, $\mathrm{p}<0.001)$. SIMPER analysis showed that differences between flocks of birds were due mainly to higher abundance of olive sunbird (Nectarinia olivacea), collared sunbird (Anthreptes collaris) and black-headed apalis (Apalis melanocephala) in forest fragments, while yellow-streaked greenbul (Phyllastrephus flaviostriatus) and Shelley's greenbul (Andropadus masukuensis) were attracted more frequently in continuous forest (Table 3).

\section{Discussion}

Highlighted in this special issue are understorey insectivorous birds from tropical forests, which, as compared to other guilds, are among the most negatively impacted by deforestation, fragmentation and habitat degradation in the tropics (Şekercioğlu et al., 2002; Bregman et al., 2014; Powell et al., 2015). Just over two-thirds of the species that participated in mixed-species flocks in the EUM forage primarily in the understorey (35\%), or in both the understorey and canopy (32\%). Of the latter grouping, we wish to emphasise that plasticity of foraging height among some of these species may be driven by seasonality, or by frequent occurrence in mixed-species flocks (Dinesen, 1995; Zou et al., 2011; Farine and Milburn, 2013). For example, an African Andropadus greenbul species increased its foraging height from a median of 5-6 $\mathrm{m}$ when not participating in flocks to 13 $\mathrm{m}$ when it joined flocks (Dinesen, 1995). Given the complexity of defining species as solely belong to a single forest stratum we therefore consider the entire $67 \%$ of species that forage partially or primarily in the understorey as relevant to the focus of this special issue.

To our knowledge, this study is the first to report on forest fragmentation and its impact on heterogeneous mixed-species flocks in an Afrotropical forest. In an earlier study, Peters et al. (2008) focused on understorey ant-following flocks in western Kenya, which is altogether a different type of flock that specifically follows army ants as they move along the floor of African forests. Furthermore, our study also appears to be one of the first to experimentally test the role of a nuclear species as an explanation for depauperate forest bird communities in small, isolated fragments, offering us an initial understanding of the importance of such mutualistic relationships.

Forest fragmentation in the EUM produced mixed-species flocks that were smaller than those in the continuous forest, and as a consequence of fewer individuals, they also comprised fewer species. Our results are comparable to several other tropical studies that examined flocks along disturbance gradients. Maldonado-Coelho and Marini $(2000,2004)$ also found that heterogeneous flocks that were smaller in size and were lower in species richness in small than large fragments of the Atlantic Forest of eastern Brazil. Working along an urban to rural gradient in Malaysia, Lee et al. (2010) also found that the species richness in mixed-species flocks decreased by almost $55 \%$ in urban as opposed to forest interior habitats. Conversely, in India (Sridhar and Sankar, 2008), Amazonian Brazil (Mokross et al., 2014), and the Andes (Colorado and Rodewald, 2015), species richness did not change or increased in forest fragments versus continuous forest. The context of habitat heterogeneity, including regenerating vegetation around fragments, can buffer negative impacts on mixed-species flocks (Maldonado-Coelho and Marini, 2000; Brandt et al., 2009; Mokross et al., 2014). In the EUM, tea plantations may present a barrier to dispersal, at least for understorey dwellers (Newmark, 1991). This factor, together with empirical evidence showing that smaller fragments maintain low diversity avian communities due to area effects (Newmark, 1991; Stratford and Stouffer, 1999), may in part explain more impoverished naturally occurring flocks in the EUM. While both insectivorous and omnivorous flocking species occurred in lower abundance and species richness in small fragments as compared to continuous forest, understorey insectivores 
showed the highest decrement. Similar results showing loss of insectivorous flocking species, especially from the understorey of African (Peters et al., 2008) and South American forests

Variability in flock composition in the EUM provides another tier towards understanding mixedspecies flocks in fragmented forests. Mixed-species flocks in the EUM fragments were significantly more variable than those in continuous forest, consistent with evidence from ant-following mixedspecies flocks in Kenyan fragments (Peters et al., 2008) and mixed-species heterogeneous and understorey flocks of the Atlantic forests of Brazil (Maldonado-Coehlo and Marini, 2004). While we did not mark flocking individuals to evaluate home range sizes, we reason that a core of the individuals and species that strongly associate with flocking maintain stable territories that contribute to the regularity of flock formation (Greig-Smith, 1978; Goodale and Beauchamp, 2010). Thus, lower stability and higher variability of flocks in small fragments is likely explained by (i) territory sizes being too large to be encompassed in such areas compared to continuous forest (Maldonado-Coehlo and Marini, 2004; van Houtan et al., 2006), and (ii) most of the flocking species in fragments are not regular flock members, since many regular member species in continuous forest are not present or very rare in fragments.

In forest fragments, the reduced abundance of individuals of regular flocking species, and not the lower species richness of the species pool from which the flocks were drawn, largely explains why flocks were markedly species-poor. Moreover, highly variable flock structure in fragments (Table 2, Fig. 3a) appears to be because a number of facultative species (including forest generalists and nonforest visitors) irregularly joined the flocks in fragments. This pattern was upheld for mixedspecies flocks attracted by playback of the drongo vocalisations. Even in this case, flocks were drawn from equally-sized (i.e. similar species richness) pools of species from inside as well as outside the forest, comparable to findings elsewhere (Maldonado-Coehlo and Marini, 2004; Sridhar and Sankar, 2008); however, the compositional differences in flocks between continuous forests and fragments were very marked (Table 3, Fig. 3b). Flock stability is likely driven by flock leaders or nuclear species, and a number of studies have suggested that loss of these species in forest fragments may lead to the disintegration of mixed-species flocks (Stouffer and Bierregaard, 1995; Dolby and Grubb, 1999; Maldonado-Coehlo and Marini, 2004). We used this reasoning to test if this indeed was the case in EUM fragments.

Is the square-tailed drongo (D. ludwigii) a nuclear species and will playback of its entire repertoire facilitate mixed-species flocks in fragments from which it is absent? We found that this putative sentinel nuclear species attracted a similar number of individuals and species in fragments versus continuous forest, and the distinctive compositional differences between habitats might be more due to substantially different species pools to draw from, rather than the absence of flocking species. We also found that conspecifics attracted to drongo playback were more than seven times lower in fragments; this result was further confirmed from independent census data where the abundance of D. ludwigii was three times lower in fragments. Given the similar size and species richness of assemblages attracted by playback in both habitats, this suggests that $D$. ludwigii provides a nuclear role to start flocks, even in fragments. Moreover, from our sampling of naturally occurring mixedspecies flocks, three important results corroborated the nuclear role of D. ludwigii. First, D. ludwigii occurred in almost all flocks in both habitats. Second, flocks with $D$. ludwigii were significantly larger than those without the species, and especially so in continuous forest. Third, species richness did not differ between these comparisons, suggesting that the species pools from which the flocks were drawn were equally sized. Taken together, $D$. ludwigii behaves similarly to the racket-tailed drongo (D. paradiseus; Goodale and Kotagama, 2005), a nuclear species in south-west Asian forests. As it sallies for prey, D. ludwigii is able to also sense danger, serving a dual function to 
attract heterospecifics to help flush prey, and providing protection by visually scanning the forest (Goodale and Kotagama, 2005; Satischandra et al., 2010). A number of ant-following species in Jullien, 1998) helps initiate and maintain these groups.

Central to this study is the finding that $D$. ludwigii appears imperative to flock formation in the EUM fragments. Working on two types of nuclear species in Sri Lankan forests, sentinel and intraspecifically gregarious species, Goodale and Kotagama (2005) found that playback vocalisations of the two species attracted eight times more insectivores than omnivores and frugivores, when played in combination and only three times more when played independently, (Kotagama and Goodale 2004). Given that nuclear species provide a number of positive interactions with heterospecific flocking species, increasing beneficial associations (Hino, 1998; Srinivasan et al., 2010), and especially among other insectivores, the higher the likelihood that a loss in these species from fragments could cascade into diminished avian communities in tropical forest fragments (Stouffer and Bierregaard, 1995; van Houtan et al., 2006, Lee et al., 2010). Dicrurus. ludwigii is often found with other putative but gregarious nuclear species such as yellowstreaked greenbul (P. flaviostriatus) and dark-backed weaver (Ploceus bicolor), which are both largely absent from smaller fragments in the EUM. The possibility of a positive-positive interaction among these three species in facilitating mixed-species flocks remains to be tested. As documented in Goodale and Kotagama's (2005) experiment, insectivores use the vocalisations of nuclear species to locate flocks, and either sentinel or gregarious equally attract these species, but having both types of nuclear species would appear to enhance flock formation. Since most of the EUM species that join mixed-species flocks are understorey foragers, and insectivores are among the guilds most negatively impacted in isolated fragments, advancing our understanding of the nuclear role of single to multiple nuclear species should be a conservation priority in this biodiversity hotspot and throughout the tropics.

\section{Acknowledgements}

We are grateful to Amani Nature Reserve for permission to conduct this research. NJC acknowledges the Tanzania Commission for Science and Technology and Tanzania Wildlife Research Institute for research clearance. The East Usambara Tea Company, Tanga Regional Forest Office, Amani Parish, The Field Museum, University of Illinois-Chicago, University of Dar es Salaam, Roosevelt University and S. Baruti, J. Bates, C. Challange, T. Challange, B. Finch, K.M. Howell, J. Keyyu, M. Kijazi, S. Mashauri, C. Mlingwa, D. Moyer, L. Mshana, A. Msisiri, B. Mtui, E. Nashanda, E. Mulungu, H. Ndangalasi, W. Newmark, the late C. Sawe, and C. Whelan offered logistical support for which we are grateful. This study was supported in part by the National Science Foundation (2001-2005, DEB 0089598, DEB 0344583), and partially by Roosevelt University. Finally, we thank Gabriel Colorado, Mauro Galetti, Eben Goodale, Alex Kirschel, Luke Powell and an anonymous reviewer for exceptional criticism that greatly improved this paper.

\section{References}

Anderson, M.J., 2006. Distance-based tests for homogeneity of multivariate dispersions. Biometrics $62,245-253$.

Arcilla, N., Holbech, L.H., Kolani, Z., 2015. Recent declines of Upper Guinea forest understory birds as indicators of unsustainable logging and illegal forest exploitation in Ghana, West Africa. Biol. Conserv. This SI issue.

Bates, D., Maechler, M., Bolker, B.M., 2013. lme4: Linear mixed-effects models using S4 classes. R package version 0.999999-2.

Bennun, L., Pomeroy, D., Dranzoa, C., 1996. The forest birds of Kenya and Uganda. J. E. Afr. Nat. Hist. 85, 23-48.

Birds of Africa (1986-2004). Academic Press (vols. 1-6), Chrisopher Helm (vol. 7). 
Bregman, T.P., Sekercioglu, C.H., Tobias, J.A., 2014. Global patterns and predictors of bird species responses to forest fragmentation: Implications for ecosystem function and conservation. Biol. Conserv. 169, 372-383.

Buechley, E.R, Şekercioğlu, C.H., Duguma, G., Ndungu, J.K., Abdu, B., Beyene, T., Muleta, D., Lens, L., 2015. Importance of Ethiopian shade coffee farms for forest bird conservation. Biol. Conserv. This SI issue.

Clark C.W., Mangel, M., 1984. Foraging and flocking strategies-information in an uncertain environment. Am. Nat. 123, 626-641.

Clarke, K.R., 1993. Nonparametric multivariate analyses of changes in community structure. Aust. J. Ecol. 18, 117-143.

Colorado, G.J., Rodewald, A.D., 2015. Response of mixed-species flocks of specialist insectivore birds to habitat alteration and deforestation in the Andes. Biol. Conserv. This SI issue.

Colwell, R.K., 2013. EstimateS: Statistical estimation of species richness and shared species from samples. Department of Ecology and Evolutionary Biology, University of Connecticut, Storrs, Connecticut, USA.

Cruz-Angón, A., Sillett, T.S., Greenberg, R., (2008). An experimental study of habitat selection by birds in a coffee plantation. Ecology 89, 921-927.

Dinesen, L., 1995. Seasonal variation in feeding ecology of Shelley's greenbul in subtropical evergreen forests. Afr. J. Ecol. 33, 420-425.

Dolby, A.S., Grubb Jr. T.C., 2000. Social context affects risk taking by a satellite species in a mixed-species foraging group. Behav. Ecol. 11, 110-114.

Farine, D.R., Milburn, P.J., 2013. Social organisation of thornbill-dominated mixed-species flocks using social network analysis. Behav. Ecol. Sociobiol. 67, 321-330.

Goodale, E., Beauchamp, G., 2010. The relationship between leadership and gregariousness in mixed-species bird flocks. J. Avian Biol. 41, 99-103.

Goodale, E., Kotagama, S.W., 2005. Alarm calling in Sri Lankan mixed-species bird flocks. Auk 122, 108-120.

Goodale, E., Kotagama, S.W., Shankar Raman, T.R., Sidhu, S., Goodale, U., Parker, S., Chen, J., 2013. The response of birds and mixed-species bird flocks to human-modified landscapes in Sri Lanka and southern India. For. Ecol. Manag. In Press <http://www.sciencedirect.com/science/article/pii/S0378112713005495>.

Gotelli, N.J., Colwell, R.K., 2001. Quantifying biodiversity: procedures and pitfalls in the measurement and comparison of species richness. Ecol. Lett. 4, 379-391.

Greenberg, R., 2000. Birds of many feathers: the formation and structure of mixed species flocks of forest birds. In: Boinski, S., and Gerber, P.A. (Eds.) On the move: How and why animals travel in groups, Chicago: University of Chicago Press, pp. 521-558.

Greig-Smith, P.W., 1978. The formation, structure and function of mixed-species insectivorous bird flocks in West African savanna woodland. Ibis 120, 284-297.

Greig-Smith, P.W., 1981. The role of alarm responses in the formation of mixed-species flocks of heathland birds. Behav. Ecol. Sociobiol. 8, 7-10.

Hamilton, A.C., Bensted-Smith, R., (Eds.) 1989. Forest conservation in the East Usambara Mountains, Tanzania. IUCN: Gland.

Hammer, Ø., Harper, D.A.T., Ryan, P.D., 2001. PAST: Paleontological Statistics Software Package for Education and Data Analysis. Palaeontol. Electron. 4, 9.

Hino, T., 1998. Mutualistic and commensal organization of avian mixed-species foraging flocks in a forest of western Madagascar. J. Avian Biol. 29, 17-24.

Hutto, R.L., 1994. The composition and social organization of mixed species flocks in a tropical deciduous forest in Western Mexico. Condor 96, 105-118.

Jullien, M., Clobert, J., 2000. The survival value of flocking in Neotropical birds: reality or fiction? Ecology 81, 3416-3430.

Jullien, M., Thiollay, J.M., 1998. Multi-species territoriality and dynamics of neotropical forest understory bird flocks. J. Anim. Ecol. 67, 227-252. 
Kotagama, S. W., Goodale, E., 2004. The composition and spatial organization of mixed-species flocks in a Sri Lankan rainforest. Forktail 20, 63-70.

Legendre, P., Legendre, L., 1998. Numerical ecology, 2nd ed. Elsevier, Amsterdam, Netherlands and New York, USA.

McClure, E., 1967. The composition of mixed species flocks in lowland and sub-montane forests of Malaya. Wilson Bull. 79, 130-154.

Mkongewa, V.J., Newmark, W.D., Stanley, T.R., 2013. Breeding biology of an afrotropical forest understory bird community in northeastern Tanzania. Wilson J. Ornithol. 125, 260-267.

Moran, M.D., 2003. Arguments for rejecting the sequential Bonferroni in ecological studies. Oikos 403-405.

Moreau, R. E., 1936. Breeding seasons of birds in East African evergreen forest. Proc. Zool. Soc. Lond. 1936, 631-653.

Moynihan, M., 1962. The organization and probable evolution of some mixed-species flocks of Neotropical birds. Smithsonian Miscellaneous Collections 143, 1-140.

Munn, C. A., Terborgh, J. W., 1979. Multi-species territoriality in Neotropical foraging flocks. Condor 81, 338-347.

Newmark, W.D., 1991. Tropical forest fragmentation and the local extinction of understory birds in the East Usambara Mountains, Tanzania. Conserv. Biol. 5, 67-78.

Newmark, W.D., 1998. Forest area, fragmentation, and loss in the Eastern Arc Mountains: implications for the conservation of biological diversity. J. E. Afr. Nat. Hist. 87,29-36.

Oksanen, J., Blanchet, G., Kindt, F., Legendre, R., Minchin, P., O’Hara, P.R., Simpson, R.B., Solymos, G.L., Stevens, P., Wagner, H.H., 2013. vegan: Community Ecology Package. R package version 2.0.

Perneger, T.V., 1998. What's wrong with Bonferroni adjustments. Brit. Med. J. 316, 1236-1238.

Powell, G.V.N., 1985. Sociobiology and adaptive significance of interspecific foraging flocks in the Neotropics. Ornith. Monogr. 36, 713-732.

Powell, L.L., Cordeiro, N.J., Stratford, J.A., 2015. Ecology and conservation of avian insectivores of the tropical rainforest understory: an introduction to this special issue. Special Issue. Biol. Conserv.

R Core Team, 2012. R: A Language and Environment for Statistical Computing. R Foundation for Statistical Computing, Vienna, Austria.

Roback, P.J., Askins, R.A., 2005. Judicious use of multiple hypothesis tests. Conserv. Biol. 19, 261-267.

Rudel, T.K., 2013. The national determinants of deforestation in sub-Saharan Africa. Phil. Trans. Royal Soc. B: Biol. Sci. 368: doi 10.1098/rstb.2012.0405

Satischandra, S.H.K., Kudavidanage, E.P., Kotagama, S.W., Goodale, E., 2007. The benefits of joining mixed-species flocks for a sentinel nuclear species, the Greater Racket-tailed Drongo Dicrurus paradiseus. Forktail 23, 145-148.

Satischandra, S. H. K, Kodituwakku, P., Kotagama S. W., Goodale, E., 2010. Assessing "false" alarm calls by drongo (Dicrurus paradiseus) in mixed-species bird flocks. Behav. Ecol. 21, 396-403.

Schielzeth, H., 2010. Simple means to improve the interpretability of regression coefficients. Methods Ecol. Evol. 1, 103-113.

Şekercioğlu, C.H., Ehrlich, P.R., Daily, G.C., Aygen, D., Goehring, D., Sandi, R.F., 2002. Disappearance of insectivorous birds from tropical forest fragments. Proc. Nat. Acad. Sci. USA 99, 263-267.

Sridhar, H., Beauchamp, G., Shanker, K., 2009. Why do birds participate in mixed-species foraging flocks? A large-scale synthesis. Anim. Behav. 78, 337-347.

Sridhar, H., Sankar, K., 2008. Effects of habitat degradation on mixed-species bird flocks in Indian rain forests. J. Trop. Ecol. 24, 134-147. 
Stotz, D.F., 1993. Geographic variation in species composition of mixed species flocks in lowland humid forests in Brazil. Papeis Avulsos Zoologia 38, 61-75.

Stouffer, P. C., Bierregaard, R. O., 1995. Use of Amazonian forest fragments by understory insectivorous birds. Ecology 76, 2429- 2445.

Stratford, J.A., Stouffer, P.C., 1999. Local extinctions of terrestrial insectivorous birds in a fragmented landscape near Manaus, Brazil. Conserv. Biol. 13, 1316-1326.

Swynnerton, C. F. M., 1915. Mixed bird parties. Ibis 67, 346-354.

Terborgh, J., 1990. Mixed flocks and polyspecific associations: costs and benefits of mixed groups to birds and monkeys. American. J. Primatol. 21, 87-100.

Thiollay, J.M., 1999. Frequency of mixed-species flocking in tropical forest birds and correlates of predation risk: an intertropical comparison. J. Avian Biol. 30, 282-294.

Thiollay, J.M., Jullien, M., 1998. Flocking behaviour of foraging birds in a neotropical rain forest and the antipredator defence hypothesis. Ibis 140, 382-394.

van Houtan, K.S., Pimm, S.L., Bierregaard Jr, R.O., Lovejoy, T.E., Stouffer, P.C., 2006. Local extinctions in flocking birds in Amazonian forest fragments. Evol. Ecol. Res. 8, 129-148.

Verhoeven, K.J.F., Simonsen, K.L., McIntyre, L.M., 2005. Implementing false discovery rate control: increasing your power. Oikos 108, 643-647.

Vernon, C.J., 1980. Bird parties in central and South Africa. In: Johnson, D.N. (Ed.), Proc. IV PanAfrican Ornithological Congress, Mahé, Seychelles, 6-13 November 1976. Johannesburg: Southern African Ornithological Society. pp. 313-325.

Winterbottom, J. M., 1943. On woodland bird parties in Northern Rhodesia. Ibis 85, 437-442.

Zou, F., Chen, G., Yang, Q., Fellows, J.R., 2011. Composition of mixed-species flocks and shifts in foraging location of flocking species on Hainan Island, China. Ibis 153, 269-278. 
Table 1. Results of Generalized Linear Mixed Models assessing the effect of forest area on mixedspecies bird foraging flocks. In all models, sites were entered as a random effect. Positive estimates indicate higher values in larger forest fragments and continuous forest. As explained in the methods section, for all species, insectivores and omnivores, the response variable in the models was the number of individuals (or species richness) in the flock, while for non-forest (includes forest generalists) and understorey specialists, the response variable was the percentage of individuals (or species richness) of that group in the entire flock.

Models

a) number of individuals

All species

Insectivores

Omnivores

Non-forest species (includes forest generalists)

Understorey specialists

b) species richness

All species

Insectivores

Omnivores

Non-forest species (includes forest generalists)

Understorey specialists
Estimate \pm St.Err.

$\mathrm{P}$

$\begin{array}{cc}0.43 \pm 0.05 & <0.001 \\ 0.58 \pm 0.05 & <0.001 \\ 0.31 \pm 0.06 & <0.001 \\ -0.071 \pm 0.010 & <0.001 \\ 0.040 \pm 0.013 & 0.006\end{array}$

$\begin{array}{cc}0.24 \pm 0.04 & <0.001 \\ 0.37 \pm 0.05 & <0.001 \\ 0.11 \pm 0.04 & 0.001 \\ -0.075 \pm 0.015 & <0.001 \\ 0.070 \pm 0.012 & <0.001\end{array}$


Table 2. SIMPER analysis of naturally occurring flocks. The table shows the species' diet (I = insectivore, $\mathrm{O}=$ omnivore), primary foraging stratum $(\mathrm{B}=$ broad, $\mathrm{C}=$ canopy, $\mathrm{U}=$ understorey; broad refers to foraging in understorey and canopy strata), forest dependency ( $\mathrm{F}=$ forest-interior, specialist species; $\mathrm{N}=$ forest generalist and non-forest species, where strictly non-forest species are denoted with an asterisk), average multivariate dissimilarity, individual and cumulative percent contribution to total observed dissimilarity, and average abundance of each species when that species is observed in flocks in continuous forest and fragments. The last two columns show frequency of occurrence, that is, the number of flocks where that species occurred divided by the total number of flocks.

\begin{tabular}{|c|c|c|c|c|c|c|c|c|}
\hline Species & Diet/Stratum/ForDer & Dissim & Contrib \% & Cumul \% & $\begin{array}{l}\text { Abund } \\
\text { (cont) }\end{array}$ & $\begin{array}{l}\text { Abund } \\
\text { (frag) }\end{array}$ & $\begin{array}{c}\text { Freq } \% \\
\text { (cont) }\end{array}$ & $\begin{array}{c}\text { Freq \% } \\
\text { (frag) }\end{array}$ \\
\hline $\begin{array}{l}\text { Yellow-streaked } \\
\text { greenbul } \\
\text { (Phyllastrephus } \\
\text { flaviostriatus) }\end{array}$ & $\mathrm{I} / \mathrm{B} / \mathrm{F}$ & 10.7 & 20.1 & 20.1 & $19.6 \pm 1.2$ & $6.6 \pm 0.6$ & 100.0 & 80.0 \\
\hline $\begin{array}{l}\text { Shelley's greenbul } \\
\text { (Andropadus } \\
\text { masukuensis) }\end{array}$ & $\mathrm{O} / \mathrm{B} / \mathrm{F}$ & 4.2 & 7.9 & 28.0 & $9.6 \pm 0.6$ & $5.2 \pm 0.5$ & 100.0 & 90.0 \\
\hline $\begin{array}{l}\text { Green barbet } \\
\text { (Buccanodon } \\
\text { olivacea) }\end{array}$ & $\mathrm{O} / \mathrm{C} / \mathrm{F}$ & 2.5 & 4.6 & 32.6 & $5.7 \pm 0.3$ & $3.7 \pm 0.4$ & 94.4 & 83.3 \\
\hline $\begin{array}{l}\text { Collared sunbird } \\
\text { (Anthreptes collaris) }\end{array}$ & $\mathrm{O} / \mathrm{B} / \mathrm{N}$ & 2.4 & 4.5 & 37.1 & $5.5 \pm 0.4$ & $3.2 \pm 0.3$ & 75.0 & 76.7 \\
\hline $\begin{array}{l}\text { Black-headed apalis } \\
\text { (Apalis } \\
\text { melanocephala) }\end{array}$ & $\mathrm{I} / \mathrm{C} / \mathrm{F}$ & 2.4 & 4.4 & 41.6 & $6.1 \pm 0.4$ & $3.9 \pm 0.2$ & 94.4 & 86.7 \\
\hline $\begin{array}{l}\text { Yellow white-eye } \\
\text { (Zosterops } \\
\text { senegalensis) }\end{array}$ & $\mathrm{O} / \mathrm{B} / \mathrm{N}$ & 2.4 & 4.4 & 46.0 & $5.3 \pm 0.5$ & $3.7 \pm 0.5$ & 66.7 & 36.7 \\
\hline $\begin{array}{l}\text { Dark-backed weaver } \\
\text { (Ploceus bicolor) }\end{array}$ & $\mathrm{O} / \mathrm{C} / \mathrm{N}$ & 2.3 & 4.3 & 50.4 & $5.0 \pm 0.4$ & $2.8 \pm 0.3$ & 88.9 & 76.7 \\
\hline $\begin{array}{l}\text { Olive sunbird } \\
\text { (Nectarinia olivacea) }\end{array}$ & $\mathrm{O} / \mathrm{B} / \mathrm{F}$ & 2.0 & 3.8 & 54.1 & $6.1 \pm 0.5$ & $4.2 \pm 0.3$ & 97.2 & 100.0 \\
\hline $\begin{array}{l}\text { Stripe-cheeked } \\
\text { greenbul (Andropadus } \\
\text { milanjensis) }\end{array}$ & $\mathrm{O} / \mathrm{B} / \mathrm{F}$ & 2.0 & 3.7 & 57.9 & $3.5 \pm 0.3$ & $2.3 \pm 0.4$ & 88.9 & 26.7 \\
\hline $\begin{array}{l}\text { Cabanis's greenbul } \\
\text { (Phyllastrephus } \\
\text { cabanisi) }\end{array}$ & $\mathrm{I} / / \mathrm{U} / \mathrm{F}$ & 2.0 & 3.7 & 61.5 & $3.3 \pm 0.2$ & $2.0 \pm 0.6$ & 86.1 & 16.7 \\
\hline $\begin{array}{l}\text { White-eared barbet } \\
\text { (Stactolaema leucotis) }\end{array}$ & $\mathrm{O} / \mathrm{C} / \mathrm{N}^{*}$ & 1.8 & 3.5 & 65.0 & $5.1 \pm 0.9$ & $4.5 \pm 0.5$ & 27.8 & 43.3 \\
\hline $\begin{array}{l}\text { Little greenbul } \\
\text { (Andropadus virens) }\end{array}$ & $\mathrm{O} / \mathrm{U} / \mathrm{N}$ & 1.7 & 3.1 & 68.1 & $4.3 \pm 0.3$ & $2.9 \pm 0.2$ & 88.9 & 90.0 \\
\hline $\begin{array}{l}\text { Grey cuckoo-shrike } \\
\text { (Coracina caesia) }\end{array}$ & $\mathrm{I} / \mathrm{C} / \mathrm{F}$ & 1.4 & 2.6 & 70.7 & $2.6 \pm 0.2$ & $1.5 \pm 0.2$ & 91.7 & 46.7 \\
\hline $\begin{array}{l}\text { Yellow-throated } \\
\text { woodl. Warbler } \\
\text { (Phylloscopus } \\
\text { ruficapillus) }\end{array}$ & $\mathrm{I} / \mathrm{B} / \mathrm{N}$ & 1.4 & 2.6 & 73.3 & $2.3 \pm \mathbf{0 . 2}$ & $2.5 \pm 0.4$ & 91.7 & 43.3 \\
\hline $\begin{array}{l}\text { Tiny greenbul } \\
\text { (Phyllastrephus } \\
\text { debilis) }\end{array}$ & $\mathrm{I} / \mathrm{U} / \mathrm{F}$ & 1.3 & 2.4 & 75.7 & $4.2 \pm 0.7$ & 0.0 & 41.7 & 0.0 \\
\hline $\begin{array}{l}\text { Forest batis (Batis } \\
\text { mixta) }\end{array}$ & $\mathrm{I} / \mathrm{B} / \mathrm{F}$ & 1.1 & 2.0 & 77.7 & $2.4 \pm 0.2$ & $2.0 \pm 0.0$ & 77.8 & 40.0 \\
\hline Square-tailed drongo & $\mathrm{I} / \mathrm{C} / \mathrm{N}$ & 1.0 & 1.9 & 79.7 & $2.7 \pm 0.2$ & $2.0 \pm 0.1$ & 86.1 & 86.7 \\
\hline
\end{tabular}


(Dicrurus ludwigii)

Uluguru violet-

backed sunbird

(Anthreptes

$\mathrm{I} / \mathrm{C} / \mathrm{F}$

1.0

1.8

81

$2.4 \pm 0.2 \quad 1.5 \pm 0.2$

$58.3 \quad 20.0$

neglectus)

Banded green sunbird

(Anthreptes

$\mathrm{O} / \mathrm{C} / \mathrm{F}$

$1.0 \quad 1.8$

rubritorques)

Black-fronted

bushshrike

(Malaconatus

$\mathrm{I} / \mathrm{C} / \mathrm{F}$

0.9

1.7

85.0

$1.8 \pm 0.2 \quad 1.2 \pm 0.2$

$69.4 \quad 20.0$

multicolor)

Green-headed oriole

(Oriolus

$\mathrm{O} / \mathrm{C} / \mathrm{N}$

0.9

1.7

86.7

$2.0 \pm 0.2 \quad 1.3 \pm 0.1$

$66.7 \quad 50.0$

$\mathrm{I} / \mathrm{B} / \mathrm{N}$

0.8

1.5

88

(Terpsiphone viridis)

Evergreen forest

warbler (Bradypterus

$\mathrm{I} / \mathrm{U} / \mathrm{F}$

0.7

1.3

89

$\mathrm{I} / \mathrm{U} / \mathrm{F}$

0.6

1.1

90.5

White-chested alethe

Moustached

tinkerbird

(Pogoniulus

leucomystax)

White-tailed cr.

Flycatcher (Elminia

albonotata)

Amani sunbird

(Anthreptes

pallidigaster)

Black-backed

puffback (Dryoscopus

$\mathrm{I} / \mathrm{B} / \mathrm{N}^{*}$

$\mathrm{O} / \mathrm{C} / \mathrm{F}$

0.6

1.1

91.

$1.3 \pm 0.1 \quad 1.1 \pm 0.1 \quad 75.0$

53.3

cubla)

Olive woodpecker

(Mesopicos

$\mathrm{I} / \mathrm{B} / \mathrm{F}$

$\mathrm{I} / \mathrm{U} / \mathrm{F}$

0.6

1.1

92.7

$1.6 \pm 0.2 \quad 1 \pm 0.0$

$47.2 \quad 3.3$

$\mathrm{I} / \mathrm{C} / \mathrm{F}$

0.6

1.1

93.8

$1.7 \pm 0.1 \quad 1.7 \pm 0.2 \quad 38.9$

23.3

griseocephalus)

Mombasa

woodpecker

(Campethera

mombassica)

Bar-tailed trogon

(Apaloderma

vittatum)

Pale-breasted

illadopsis (Illadopsis

rufipennis)

$\mathrm{I} / \mathrm{U} / \mathrm{F}$

0.6

1.0

94.8

$2 \pm 0$

$1.6 \pm 0.2$

25.0

26.7

Scaly-throated

honeyguide (Indicator

$\mathrm{I} / \mathrm{C} / \mathrm{N}$

$0.4 \quad 0.7$

95.

$\mathrm{I} / \mathrm{C} / \mathrm{N}$

$0.3 \quad 0.5$

96.0

$1.7 \pm 0.2 \quad 1.3 \pm 0.3$

$16.7 \quad 10.0$

variegatus)

Fischer's turaco

(Tauraco fischeri)

$\mathrm{O} / \mathrm{C} / \mathrm{N}$

0.2

0.3

97.6

$0.0 \quad 2.3 \pm 0.3$

$0.0 \quad 10.0$

Red-tailed ant thrush

(Neocossyphus rufus)

$\mathrm{I} / \mathrm{U} / \mathrm{F}$

0.2

0.3

97.

Sharpe's akalat

I/U/F

0.2

98. 
(Sheppardia sharpei)

African dusky

flycatcher (Muscicapa

$\begin{array}{lllllll}0.1 & 0.2 & 98.4 & 4.0 \pm 0.0 & 0.0 & 5.6 & 0.0\end{array}$

adusta)

Long-billed tailorbird

(Artisornis moreaui)

Cardinal woodpecker

(Dendropicos

fuscescens)

Eastern nicator

(Nicator gularis)

Yellowbill

(Ceuthmochares

aereus)

Olive thrush (Turdus

abyssinicus)

$0.1 \quad 0.2$

$\mathrm{I} / \mathrm{B} / \mathrm{N}^{*}$

$0.1 \quad 0.2$

98.8

$\begin{array}{lll}0.0 & 2.0 \pm 0.0 & 0.0\end{array}$

White-starred robin

(Pogonocichla stellata)

$\mathrm{I} / \mathrm{B} / \mathrm{N}$

$0.1 \quad 0.2$

99.

$\mathrm{I} / \mathrm{C} / \mathrm{N}^{*}$

$0.1 \quad 0.2$

99.2

$\begin{array}{lll}0.0 & 2.0 \pm 0.0 & 0.0\end{array}$

6.7

$\mathrm{O} / \mathrm{U} / \mathrm{F}$

0.1

0.1

99.

$\mathrm{I} / \mathrm{U} / \mathrm{N}$

0.1

0.1

99.

$4.0 \pm 0.0 \quad 0.0$

$2.8 \quad 0.0$

Brown-crowned

tchagra (Tchagra

I/U/N*

0.1

0.1

99.6

$\begin{array}{lll}0.0 & 2.0 \pm 0.0 \quad 0.0\end{array}$

Grey-backed

camaroptera

(Camaroptera

$\mathrm{I} / \mathrm{U} / \mathrm{N}^{*}$

0.1

0.1

99.

brachyura)

Common bulbul

(Pycnonotus

$\mathrm{O} / \mathrm{B} / \mathrm{N}^{*}$

0.1

0.1

99.8

$\begin{array}{lll}0.0 & 1.0 \pm 0.0 & 0.0\end{array}$

6.7

African broadbill

(Smithornis capensis)

I/U/F

0.1

0.1

99.9

$1.0 \pm 0.0 \quad 0.0$

$8.3 \quad 0.0$

Red-faced

crimsonwing

(Cryptospiza

$\mathrm{O} / \mathrm{U} / \mathrm{N}$

0.1

0.1

100.0

$\begin{array}{lll}0.0 & 1.0 \pm 0.0 & 0.0\end{array}$

3.3 
Table 3. SIMPER analysis of assemblages attracted by playback of square-tailed drongo (Dicrurus ludwigii) vocalisations. The table shows average multivariate dissimilarity, individual and

Species

Olive sunbird (Nectarinia olivacea)

Black-headed apalis (Apalis melanocephala)

Yellow-streaked greenbul (Phyllastrephus flaviostriatus)

Collared sunbird (Anthreptes collaris)

Little greenbul (Andropadus virens)

Green barbet (Buccanodon olivacea)

Shelley's greenbul (Andropadus masukuensis)

Dark-backed weaver (Ploceus bicolor)

Grey-backed camaroptera (Camaroptera brachyura)

White-eared barbet (Stactolaema leucotis)

Uluguru violet-backed sunbird (Anthreptes neglectus)

Black-backed puffback (Dryoscopus cubla)

Pale batis (Batis soror)

Green-headed oriole (Oriolus chlorocephalus)

Grey cuckoo-shrike (Coracina caesia)

Forest batis (Batis mixta)

Black-throated wattle-eye (Platysteira peltata)

Moustached tinkerbird (Pogoniulus

leucomystax)

Fischer's turaco (Tauraco fischeri)

Black-fronted bush-shrike (Malaconatus multicolor)

Pale-breasted illadopsis (Illadopsis rufipennis)

Stripe-cheeked greenbul (Andropadus milanjensis)

Banded green sunbird (Anthreptes rubritorques)

Yellow-throated woodland warbler (Phylloscopus ruficapillus)

Tiny greenbul (Phyllastrephus debilis)

Cabanis's greenbul (Phyllastrephus cabanisi)

Tropical bulbul (Laniarius aethiopicus)

Common bulbul (Pycnonotus barbatus)

White-crested alethe (Alethe fuelleborni)
Dissim.

Contrib. $\%$

7.861

6.262

5.639

5.477

5.006

4.607

3.29

3.048

2.16

2.049

2.89

2.02

2.849

1.989

2.805

1.984

1.784

1.713

1.493

1.388

1.307

1.168

1.092

1.647

1.54

1.045

1.474

0.9687

1.366

0.821

1.158

0.8048

1.135

0.6624

0.9343

0.6392

0.9016

0.6015

0.8484

0.5961

0.8408

0.5788
Cumul. \%

11.09

19.92

27.88

35.6

42.66

49.16

53.8

58.1

61.15

64.04

66.89

69.69

72.49

75

77.42

79.53

81.49

83.33

84.98

86.52

87.99

89.36

90.51

91.65

92.58

93.49

94.33

95.17

95.99
Abund. Abund. (cont) (frags)

1.44

3.11

$1.11 \quad 2.56$

2.33

0.778

0.333

2.22

1.44

1.44

1.89

1.22

1.22

0.556

0.667

0.667

0.667

$0.111 \quad 0.667$

0.556

0.222

\section{$0.111 \quad 0.667$}

$\begin{array}{ll}0 & 0.778\end{array}$

0.556

0.111

0.333

0.444

0.333

0.222

0.444

0.444

$0.222 \quad 0.222$

0.333

0

0.3330

0.222

0.222

$0.111 \quad 0.222$

0.222

0

$0.222 \quad 0$

$0.111 \quad 0.111$

0

0.222

0.111

0.111

0.222

0 
Yellow white-eye (Zosterops senegalensis)

0.4005

0.5649

96.56

0

0.111

African Dusky flycatcher (Muscicapa adusta)

0.4005

0.5649

97.12

0

0.111

Evergreen forest warbler (Bradypterus mariae)

0.3924

0.5535

97.67

0.111

0

Amani sunbird (Anthreptes pallidigaster)

0.3783

0.5336

98.21

0.3376

0.4762

98.68

0.111

0

Tambourine dove (Turtur tympanistria)

0.3376

0.4762

99.16

0

0.111

reichenovii)

African broadbill (Smithornis capensis)

Long-billed tailorbird (Artisornis moreaui)

0.4671

99.63

0.111

0.111

0.3312

0.3722

100

0

0.2638
0

0.111 
1 Fig. 1. Effects of forest area on the composition of 66 naturally occurring mixed-species foraging

2 flocks. Graphs in the left column show analyses where flock size was the response variable, while

13 in the right column the response variable was flock species richness. Lines represent GLMM model

24 estimates and their $95 \%$ confidence intervals.

35

$\begin{array}{ll}4 & 5 \\ 5 & 6\end{array}$

$\begin{array}{ll}5 & 6 \\ 6 & 7\end{array}$

78

89

${ }_{10}^{9} 10$
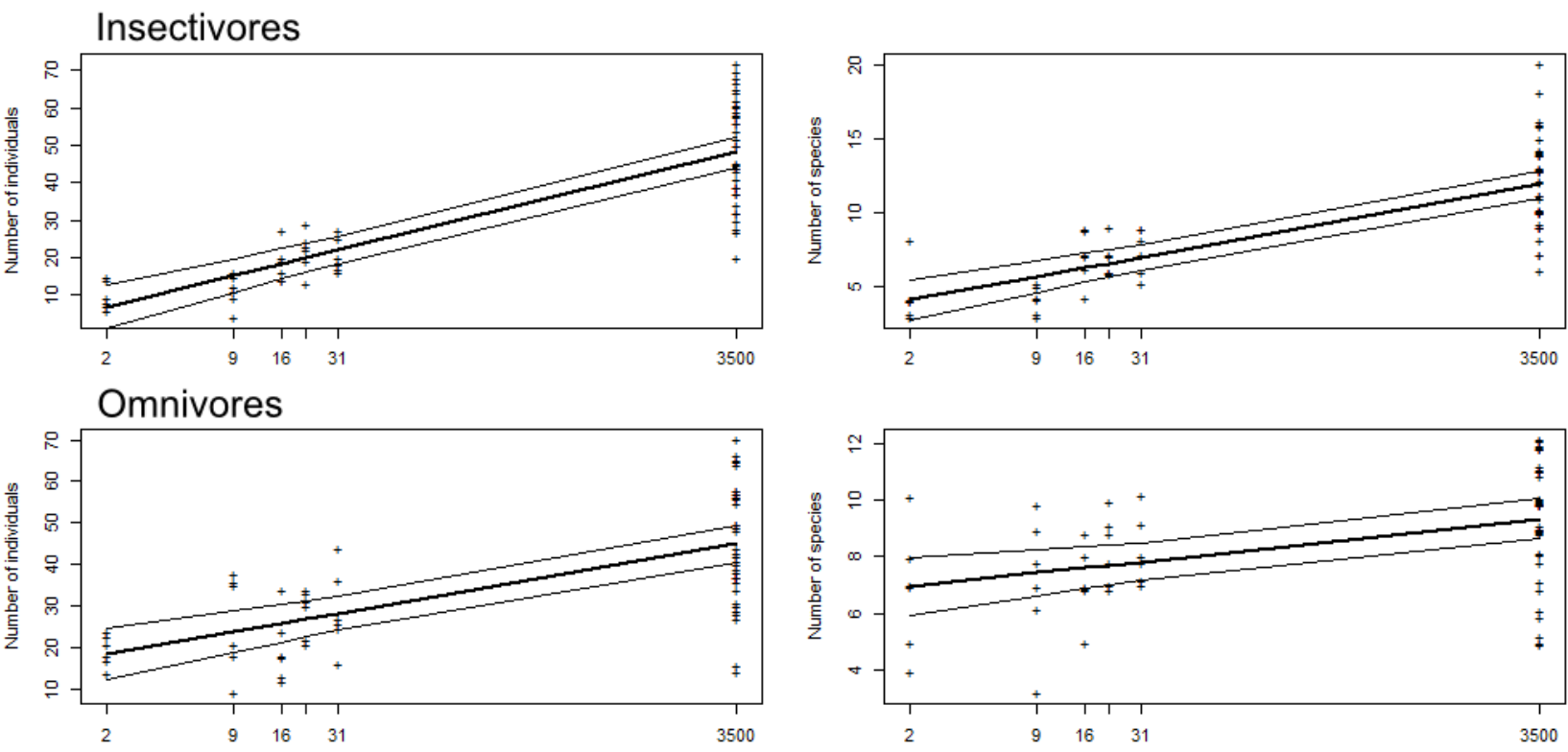

Forest generalists and non-forest species
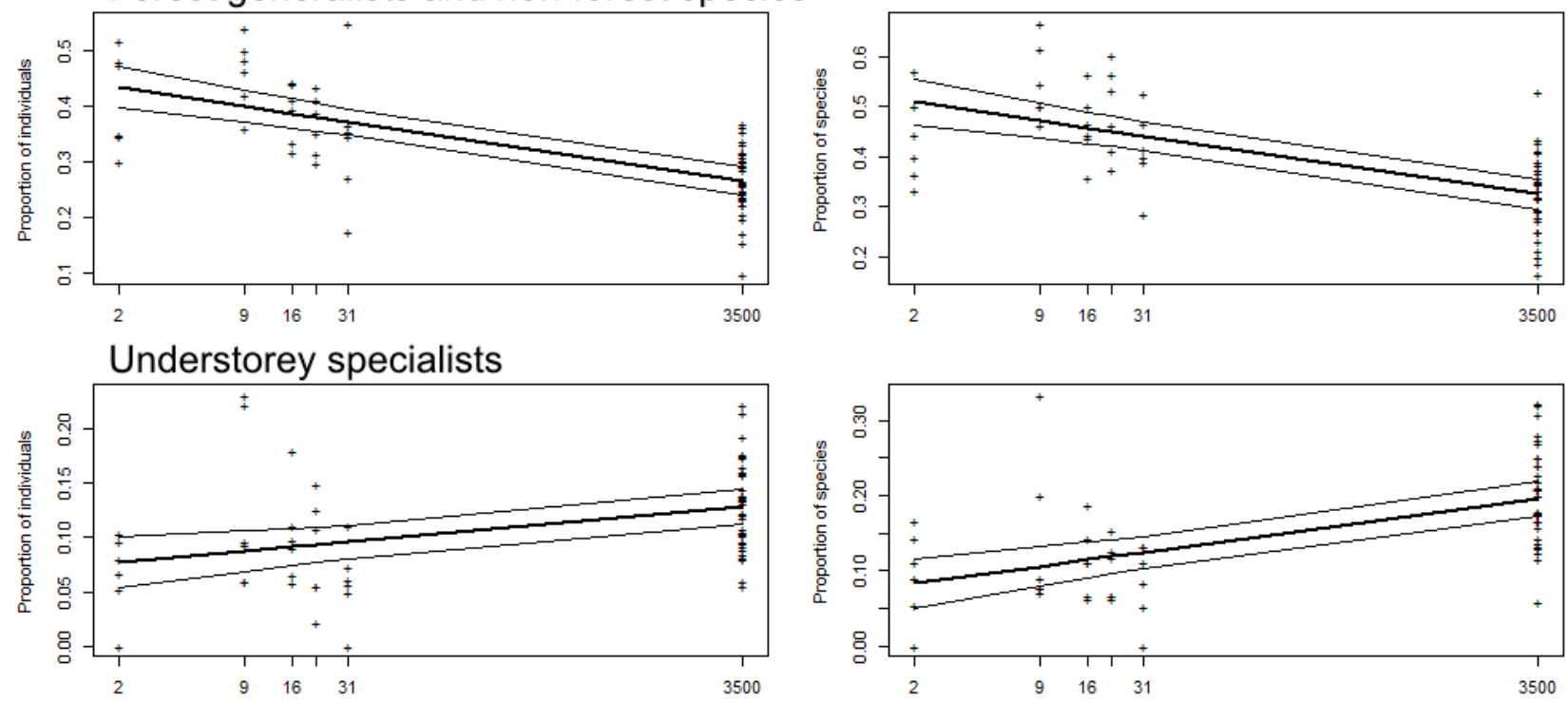

Fragment area (ha) 
53 Fig. 2. Species rarefaction curves of mixed-species foraging flocks (a) observed in continuous

54 forest and forest fragments, and (b) attracted by playback of square-tailed drongo (Dicrurus

155 ludwigii) vocalisations in continuous forest and forest fragments. Thin lines represent unconditional $25695 \%$ confidence limits of the two curves.

${ }_{4}^{3} 57$
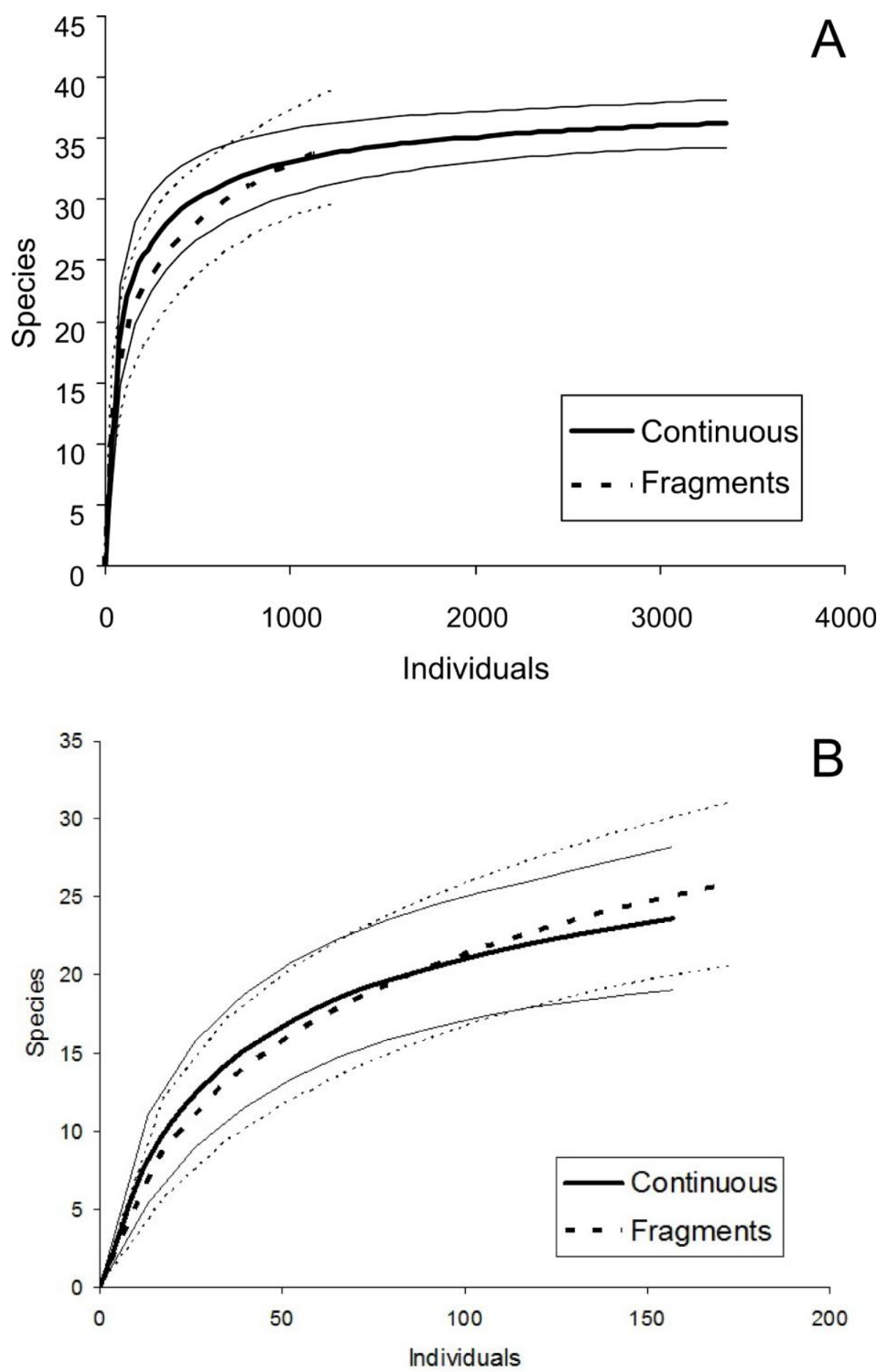
63 Fig. 3. Detrended Correspondence Analysis plots of (a) 66 naturally occurring mixed-species bird 64 flocks, and (b) 18 assemblages of birds attracted by playback of square-tailed drongo (Dicrurus 165 ludwigii) vocalisations. Filled dots = continuous forest; open dots = forest fragments. Thin lines 266 show the convex hulls enclosing all the points of the two habitat types.
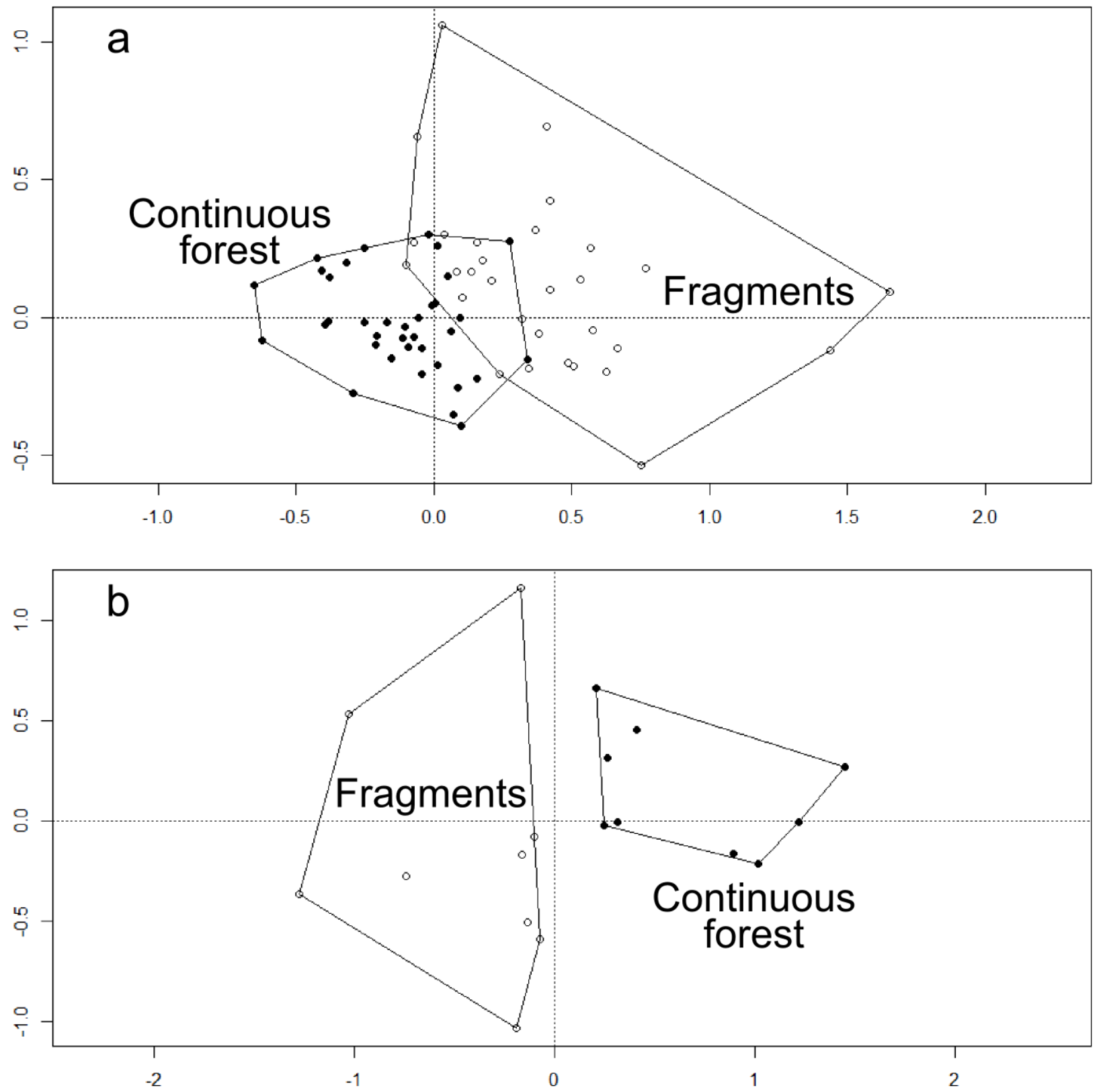